Journal of Contemporary Research in Business, Economics and Finance

ISSN: 2641-0265

Vol. 3, No. 4, pp. 84-108.

2021

Publisher: Learning Gate

DOI: $10.33094 / 26410265.2021 .34 .84 .108$

(C) 2021 by the authors; licensee Learning Gate

\title{
Lean Management Practices' Effects on Brazilian Firms: A Quantitative and Qualitative Analysis
}

\author{
Filipe Lage de Sousa* \\ Advanced Academic Programs, Master's in Applied Economics, John Hopkins University, USA. \\ Email: flagede1@jhu.edu (*Corresponding Author) \\ Mauricio Canêdo-Pinheiro \\ Brazilian School of Economics and Finance, Getulio Vargas Foundation (FGV/EPGE), Rio de Janeiro, Brazil; Rio de Janeiro State \\ University (UERJ), Rio de Janeiro, Brazil. \\ Email: mauricio.canedo.pinheiro@gmail.com \\ Bernardo Pereira Cabral \\ Department of Economics, Federal University of Bahia (UFBA), Salvador, Brazil. \\ Email: Bernardopcabral@gmail.com \\ Glaucia Estefânia de Sousa Ferreira \\ Institute for Applied Economic Research (IPEA), Rio de Janeiro, Brazil. \\ Email: glauciadesousaferreira@gmail.com
}

Received: 13 May 2021; Revised: 25 June 2021; Accepted: 19 July 2021; Published: 23 August 2021

\begin{abstract}
One of the key drivers for a firm's productivity growth is management. One lean management practice considered cost-effective is Kaizen. Originally from Japan, the Kaizen basic concept is continuous improvement with the involvement of the full workforce. Using a firm-level dataset from Brazil's innovation and manufacturing surveys, this paper evaluates quantitatively whether Kaizen has impacted the performance of domestic firms. Our initial results suggest a productivity premium on Kaizen adopters, yet when it materializes is not detectable in the short term. Moreover, the impact on innovation is observable after Kaizen implementation. Understanding these outcomes with a qualitative approach, our analysis highlights the importance of Kaizen on innovation, especially by improving worker's time at the production line as well as the long-term vision of Kaizen on productivity. In summary, Kaizen is not a magic wand that improves firms' performance in a wide array of indicators yet it may boost innovation outcomes in the short term aiming to improve productivity in the long term if it is implemented carefully and persistently, as established by its basic principles.
\end{abstract}

Keywords: Lean management; Productivity; Innovation; Impact evaluation; Manufacturing.

JEL Classification: M11; D24; O31; L60.

Funding: This research was supported by the Global Development Network (GDN) under grant reference number GDNIO/GRANT/2017-18/453/KAIZEN/TEAM BRAZIL.

\section{Introduction}

A standard way to improve a firm's performance is by incorporating management methods. To increase their efficiency, firms seek new management practices as they need to compete in a changing market in order to thrive. The option for management practices is grounded by robust evidence that it improves firms' productivity, see Mahajan, Eifert, McKenzie, Roberts, and Bloom (2012) as an example. 
Moreover, a literature survey on the determinants of productivity has also listed management as an important catalyzer for productivity improvements (Syverson, 2011).

Because of this evidence, differences in productivity are partially explained by the quality of management practices. For instance, Bloom et al. (2016) estimated that differences in management practices account for about $30 \%$ of cross-country total factor productivity differences. In the international arena, management practices of the private sector in developing countries, including Brazil, are lagging in developed countries (Bloom, Genakos, Sadun, \& Van Reenen, 2012). Moreover, firms with low-quality management practices are concentrated at the bottom of the productivity distribution in developing countries (Bloom et al., 2012) which implies that improving the quality of management practices constitutes not only an opportunity to close productivity gaps between firms within a given industry in a country, but also between developed and developing countries. Japaneseoriginated lean manufacturing, named as Kaizen, is considered one of the best management practices and the reason for US productivity success (Bloom et al., 2012). Recently, scholars have been advocating for more economic analyses of management despite the expansion of the literature, see Roberts (2018) as an example.

This paper aims to make an impact evaluation on whether a lean management practice, named as Kaizen, can improve Brazilian manufacturing firms' performance by looking at quantitative and qualitative approaches. To the best of our knowledge, this is the first attempt to combine these two approaches to evaluate how lean management practices are able to boost firms' performance worldwide, which is becoming relevant for impact evaluations, as shown in Burch and Heinrich (2016). Additionally, taking the advantage of a fruitful dataset, this paper also contributes to the literature by investigating the dynamics of the introduction of a management practice. Most papers in the literature on management practices concentrate their analysis on only two periods. According to Bloom et al. (2012), future research on management should consider longer panel data to address the dynamics of managerial change, so that statements about cause and effect could be addressed, which has become a trend in the literature (see (Higuchi, Mhede, \& Sonobe, 2019; Higuchi, Nam, \& Sonobe, 2017; Karlan, Knight, \& Udry, 2015; McKensie \& Puerto, 2017; Valdivia, 2015)). As this paper uses three periods of information on management practice, we are contributing to the literature on the dynamics of the effects from an implementation of a management practice. This paper also distinguishes from the literature is twofold. First, our fruitful dataset permitted us to have more than one thousand firms in our investigation, contrasting to papers with a limited number of enterprises. For instance, Mahajan et al. (2012) exploited their number of observations from each firm to compensate for their limited sample size, in other words, they implemented procedures that rely upon asymptotic approximations along the time dimension with a fixed dimension of a cross-section. Second, our paper investigates medium and large firms instead of SMEs. Our argument relies on the fact that medium and large firms suffer more organizational hurdles than SMEs. Therefore, a management practice on medium and large firms might promote more evident effects since firms' structure becomes more complex, which requires an advanced management practice.

Our initial findings suggest a productivity premium for implementing Kaizen. On average, Kaizen adopters show total factor productivity $8 \%$ higher than similar non-adopters firms, which is consistent with the international literature. For instance, Mahajan et al. (2012) found an impact of $11 \%$ on productivity after the implementation of a new management practice in Indian firms and Gallego and Gutiérrez (2017) estimated 12\% in Colombian firms. However, our findings in this initial approach neglect some important unobserved features of management practices, such as ownership type. While investigating when this impact materializes after its implementation and considering other aspects (such as ownership), we were not able to detect any impact on productivity, yet robust evidence on innovation is observed. Since innovation is a relevant catalyzer for productivity improvements in the long term, our findings suggest that lean manufacturing practices may induce productivity gains after a long period. ${ }^{1}$

Higuchi et al. (2019) argues that management practices require a medium period to observe robust evidence on businesses' performance. ${ }^{1}$ 
Nevertheless, it is important to emphasize that our qualitative approach corroborates our quantitative findings that productivity is achieved only in the long term and innovation immediately. Therefore, our interpretation consists of lean manufacturing as an effective tool to raise innovation in the short term and ultimately productivity gains in the long term.

To make this assessment, this paper is organized as follows. Section 2 describes the conceptual framework that supports our quantitative and qualitative approaches. Section 3 details our data collection and empirical strategy in both approaches as well as presenting some descriptive statistics. Our results from our quantitative and qualitative approaches are discussed in Section 4, including a reflection on the combination of all methodologies. The last section provides our concluding remarks.

\section{Conceptual Framework}

The initial starting point consists of defining Kaizen. In Japanese, Kaizen means "change for better" and it was incorporated into the business environment as a management approach. Kaizen, as a management method, has several definitions as its interpretation in other languages is not straightforward to be translated. Considering all feasible definitions, we make use of one of the latest versions, which is: "Kaizen is the management philosophy and know-how that brings about continuous, participatory, incremental and low-budget improvements in quality, productivity, cost, delivery, safety, morale, and environment"(Hosono, Shimada, \& Page, 2020).

Therefore, our interpretation considers that Kaizen is characterized by a permanent search for improvements with the participation of the labor force and without large amounts of investment. The expected consequences of Kaizen are improving firms' performances in different aspects of the production line, not only in financial benefits, such as productivity gains or cost reductions but also in other aspects, such as in safety and environment. Although the objectives are like other management approaches, Kaizen differs from them on how to reach these goals. As focusing on low-cost adjustments with continuous and participatory processes, Kaizen differs from others due to their vision of implementing frequent incremental changes, mainly proposed by the workforce.

Besides Kaizen's definition, it is relevant to understand what influences the adoption of this management practice. In the management literature, some authors argue that determinants of management adoption are still not fully explored, such as Bloom et al. (2016). The main difficulty is to find reasonable previous information to some characteristics which might be exogenous to the introduction of management practice. Our analysis tries to provide some insights on this issue, but investigating Kaizen determinants is not straightforward and requires further investigation beyond the scope of this research.

Although determinants are questionable and deserve further investigation, there is robust evidence that some variables are correlated with management according to the literature, which is enough for our analysis as discussed in Section 3.

Among all, competition is considered one of the most frequent variables cited by the literature. Since the seminal paper on management across countries made by Bloom, Dorgan, Dowdy, and Van Reenen (2007) higher levels of competition lead to better management levels, which was corroborated in a series of papers (Bloom et al., 2012; Bloom \& Van Reenen, 2010). According to the authors, there are two mechanisms by which competition impacts management practices positively. First, a self-selection process which eliminates badly managed firms relative to well-managed ones, which means that competition purges inefficient firms from the market. Second, competition drives firms to improve their management practices to survive in the market. Despite which mechanism works, the literature is robust on the positive effect of competition on management.

The other two variables are extremely related: size and growth. According to the literature, larger firms tend to be positively associated with better management practices (see (Bloom et al., 2012; Bloom \& Van Reenen, 2010; Bloom, Lemos, Sadun, Scur, \& Van Reenen, 2014)). The basic concept of this relationship is grounded on the fact that larger firms require more effort to coordinate a large and disperse number of workers within the firm, as pointed out by Gibbons and Henderson (2011). Related 
to this idea, literature also provides robust evidence that firms' growth is strongly correlated to the quality of management practice (Bloom et al., 2012; Bloom \& Van Reenen, 2010; Bloom et al., 2014). Again, as operational complexity increases due to firms' growth, higher levels of management are essential to maintain their expansion.

Additional to size and growth, management literature also presents longer survival periods for those with higher levels of management practice. In other words, there is a positive association between management and survival (Bloom et al., 2012; Bloom \& Van Reenen, 2010; Bloom et al., 2014). Moreover, there is robust evidence on the relationship between management practice with multinational status and export performance (Bloom et al., 2012; Bloom \& Van Reenen, 2010; Bloom et al., 2014).

Considering the labor force, there are two possible and exclusive correlations between management practices and human capital. One part might argue that firms with a less educated workforce require higher management practices to compensate for the lower human capital. Another feasible explanation relates higher management practices are only implemented on firms with elevated human capital. However, the literature found evidence in the second possibility, which means that firms with higher levels of human capital tend to have a superior level of management practice (Bloom et al., 2012; Bloom et al., 2007; Bloom \& Van Reenen, 2010; Bloom et al., 2014).

In financial terms, literature found that management practices are positively correlated with profitability (Bloom et al., 2007; Bloom et al., 2014) and market value (Bloom et al., 2014) as well as negatively correlated with cost/revenue (Bloom et al., 2012). These evidences suggest that management practices are worth implementing as financial benefits might exist. Additionally, Bloom et al. (2014) also found a positive association between management practice and measures of R\&D.

Lastly, there is robust evidence that family-owned firms tend to perform worst in terms of management practice (Bloom et al., 2007; Bloom \& Van Reenen, 2010; Bloom et al., 2014). According to the authors, family ownership limits the search for better managers as they are restricted to family members.

\section{Data and Empirical Strategy}

Based on the evidence provided in the previous section, our data and empirical strategy need to address all issues described to contribute effectively to the literature. As management has been investigated quantitatively and qualitatively separately in the literature, our analysis covers both approaches yet not jointly.

\subsection{Data for Quantitative Approach}

For quantitative investigation, we require a firm-level dataset to assess whether Kaizen can impact firms' performance. The Brazilian Statistical Institute (IBGE) provides rich and large microdata at the firm level from two relevant surveys: the Brazilian Innovation Survey (Pesquisa de Inovação TecnológicaPINTEC); and the Annual Manufacturing Survey (Pesquisa Industrial Anual- PIA). ${ }^{2}$

PINTEC is a sample survey, inspired by the Oslo Manual from OECD, which means that it is comparable to other similar surveys worldwide. Six waves of this survey are available (1998-2000, 20012003, 2003-2005, 2006-2008, 2009-2011, and 2012-2014), enabling us to follow firms over a certain period if the questions related to management practices are consistent over time. PINTEC's sample is stratified concerning firm size (number of employees), sector, state, and innovation potential. Firms with less than 10 employees are not surveyed and larger firms (with 500 or more employees) are allocated in a specific stratum and selected with probability equal to one (certain stratum). The remaining firms are allocated to sampled strata, which were defined by crossing information on state and sectors. These strata (called natural strata) are then subdivided into two strata (called final strata), one with potential

We have accessed the firm-level data from PINTEC and PIA at the IBGE headquarters in Rio de Janeiro, Brazil. PIA data covered from $1996{ }^{2}$ until 2014 and we had access to PINTEC from the years 2000, 2003, 2005, 2008, 2011 and 2014 
innovators and the other with the remaining firms. ${ }^{3}$ The sample is disproportionately allocated in these two final strata, so that approximately $80 \%$ of the firms selected for a sample, in each natural stratum, are companies very likely to be innovative. Although extremely restrictive, more than 14 thousand firms from the manufacturing sector participated in the 2014 innovation survey. ${ }^{4}$

PIA database contains information that allows us to build a measure of firm productivity and other key explanatory variables such as number of employees, investments in physical capital, and others. ${ }^{5}$ This annual survey was initiated in 1986, but a consistent approach started only after 1996 and remains the same until 2014. PIA comprehends all manufacturing firms over 30 employees, which means a census for firms over this threshold. Firms from one to 30 employees are randomly surveyed in PIA. On average, around 30,000 firms are surveyed annually in the census part (over 30 employees). ${ }^{6}$

Since the same institution (IBGE) elaborates these two surveys, they share similar methodological aspects, such as the identical sector classification, which follows the International Standard Industry Classification (ISIC). Since both datasets use the same firm identification, we can merge them.

\subsection{Empirical Strategy for Quantitative Approach \\ 3.2.1. Defining Kaizen}

From an empirical perspective, our study faces the challenge of identifying the Kaizen adoption because we do not have the information on whether a firm has implemented this management approach. However, we can develop a taxonomy to identify firms adopting management practices based on Kaizen's principles. This can be considered a contribution on using innovation surveys to define Kaizen adopters when this information is not available.

Although PINTEC provides information on whether firms have implemented management practices in all six waves of this survey, questions change over time, hampering us to use all years available. However, the last three innovation surveys provide identical questions on management. This consistency in the questionnaires enables us to create an approach to distinguish whether firms are implementing Kaizen style of management practice. Nevertheless, firms need to be present in the three waves for us to define which firms are continuously implementing a management practice, as this is a requirement for being considered a Kaizen. Therefore, we restricted our sample to a balanced panel of firms from these three waves.

In this survey, as organizational innovation, they consider any implementation of new management practice or significant changes in the division of labor within the firm as well as in the external relations with clients or suppliers. These changes must aim to improve their knowledge, efficiency in their operations or in the quality of their goods and services. They should also be a consequence of the strategic decisions of the firm's directors and a new organizational method for the firm. Although this definition seems extremely broad, they do not consider merging and acquisition as an organizational innovation, even if this is the first time.

Given this background to what is considered an organizational innovation, firms reply to the survey to whether they have implemented any new management practice to improve their routines and labor practice in the last three years. Under this concept, examples of new management practices are reengineering, knowledge management, total quality control, training activities, enterprise resource planning, and others. Therefore, replying affirmative to this question is just an indication of whether the firm could be implementing Kaizen since we do not know either if it involves all the employees or that it

\footnotetext{
In summary, potential innovators are defined by IBGE as firms that, in the survey period, were included in the registers of beneficiaries of ${ }^{s}$ innovation public policies or in the Brazilian patent registers. The ones that were innovators in the previous surveys are also defined as potential innovators.

PINTEC covers all manufacturing sector and only some from services: telecommunications, information technology, ${ }^{4}$

engineering/architecture and research \& development $(\mathrm{R} \& \mathrm{D})$. As the number of firms in these services is restrictive, we focus our analysis on

the manufacturing sector. More than 4 thousand firms participated in the certain stratum in 2014.

List of the variables used in this paper is presented in Appendix 1.5

In 2014, more than 56 thousand firms were surveyed for this publication, being 40 thousand of them from the census part. ${ }^{6}$
} 
is a continuous process. Complementary information is needed to refine the identification of the Kaizen approach.

Following this initial question on management practice, the questionnaire further asks if new methods of labor organization aiming to delegate responsibilities for achieving better decision-making, such as new managing working teams, restructuring departments, or others in a similar fashion. Since Kaizen requires labor participation to improve their operations, we consider this as a second characteristic of this management practice. ${ }^{7}$

Lastly, another feature of Kaizen is the recurrent improvements in a firm's operations. In other words, it requires continuous changes in their business practice. Therefore, we define a Kaizen management approach if a firm has answered affirmatively to both questions described previously in recurrent years. In other words, if a firm has implemented a new management practice and this new method has delegated responsibilities, both answers continuously (over time), then it is considered as a firm introducing a management practice grounded on Kaizen principles.

Considering the definition provided in previous paragraphs, the distribution of firms implementing or not a management practice in a Kaizen style is presented in Figure 1. First, our balanced panel comprehends 1,735 firms available in both datasets described previously. ${ }^{8}$ In terms of Kaizen, 795 firms have implemented this management practice over the period investigated. ${ }^{9}$ However, implementation of Kaizen occurs in distinct periods, and firms are evenly distributed over time, detected in the innovation surveys.

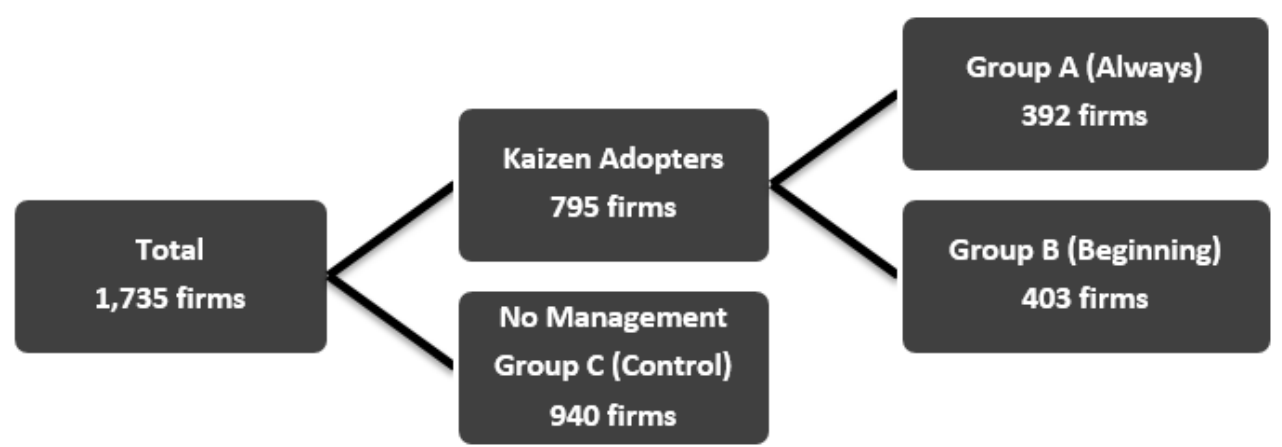

Figure-1.

Distribution of firms implementing Kaizen.

\subsubsection{Econometric Specification}

Given the distribution of firms in the categories described in the previous section, two different strategies can be pursued. Initially, our best candidates as firms implementing Kaizen are those that continuously replied "yes" to both questions over time. This comprehends those firms implementing Kaizen over the three survey years investigated (Group A). Our initial approach is to compare them with those that have not implemented any management practice (Group C).

Although Group A is the most proper group to be considered as a Kaizen management style, since they have been implemented constantly from 2006 to 2014, we don't know when they have adopted this management method. As the gains of Kaizen might be when they have started this management

Definition of organization innovation and questions used to define Kaizen are presented in Appendix 2 in its original language (Portuguese). ${ }^{7}$ We have excluded all firms which have answered erratically these two described questions, which means neither consistent across them ${ }^{8}$ and/or nor overtime. For example. a firm answering "yes" in the first year, "no" in the second and "yes" in the third is not considered in our analysis. Although this firm may be considered a treated one in a broad investigation of management, it does not fulfill the requirements to be considered a Kaizen adopter. There were 1,227 of those firms and for simplicity, we excluded them. Descriptive statistics of all firms available and those considered in this paper are presented in Appendix 3.

In preliminary results, we have also considered as Kaizen adopter firms which started to implement this management practice in the last ${ }^{9}$ innovation survey year (2014), not only jointly with Group B but also isolated. Outcomes adding those firms are not different from those presented here, which provide robust outcomes for our investigation, and are available upon request. 
approach, it is relevant to investigate when the firm begins the implementation of Kaizen. Therefore, we assume that firms carrying out the Kaizen approach based on the last two PINTEC (group B) are also candidates to investigate the effects on a firm's performance after the implementation of this management practice because they haven't introduced any in our initial period (2006-2008).

Empirical strategy to investigate the effects of Kaizen for groups A and B cannot be identical, as they have their particularities on when they have implemented this management practice. In Group A, we are not aware of when the firm started carrying out Kaizen. Therefore, our strategy should be what the bonus of implementing this Japanese management practice is. Comparing the performance between groups is an initial approach, but the adoption of management practices, considered as the "treatment variable", is not random across firms. Firms self-select themselves into treatment, and their decision may be related to the benefits or gains from the adoption, which in this case might be productivity gains. As a result, the adoption of Kaizen is endogenous. A feasible approach to tackle this endogeneity is implementing propensity score matching (PSM) and average treatment effect (ATE) sequentially. ${ }^{10}$

As for the other comparison group (B versus $\mathrm{C}$ ), we implement a combination of PSM and difference-in-differences (DID). Since we know when firms began implementing the management practice, we use pre-and post-intervention years to establish the effect. Since Kaizen adoption is endogenous, we perform a one-to-one PSM in 2008 (pre-Kaizen), select only those matched firms in the control group, and perform a DID for the whole period. DID enables us to eliminate any unobservable time-invariant characteristics which are not detectable in our PSM approach.

\subsection{Qualitative Approach}

We used a qualitative approach to counterpart the results from the quantitative analysis on Kaizen effects on Brazilian firms. Our specific goal was to elucidate potentially counterintuitive results from quantitative results and to broaden topics that could not be properly covered only with quantitative data.

We chose to focus our approach on Kaizen rather than firms, which led us to establish only one criterion: to use Kaizen in their productive activities in Brazil. To meet our goals, the selected companies were contacted by e-mail. Firms Alfa and Beta adopted Kaizen since its creation, but Gama adopted Kaizen only in 2015 because it was merged with an Asian company. We interviewed different employees from those companies and all interviews took place between March and June of 2018. The interviewees were involved with Kaizen taskforces in the companies but had different working backgrounds, ages, and positions. We aimed to interview people that were mainly connected with the production line and could provide us relevant information on Kaizen-related activities in the firm.

We used a semi-structured questionnaire with open-ended questions. An interview guide was used in the meetings to assist the researchers throughout the interviews. We used a standard questionnaire and created specific questions for each of our interviewees considering their position and working background in the firm. All the interviews were recorded and transcribed and the average time per interview was 30 minutes. The precise object of the interview was not to explicitly answer the questions but to get deeper impressions of Kaizen's activities in the firm. The interviewees were encouraged to speak freely in their answers since our questionnaire was constructed with open-ended questions. We captured information that reflected the variability needed to understand the phenomenon studied in the research (Patton, 2002), and the collected cases provided relevant examples of the phenomena under scrutiny (Siggelkow, 2007) with a minimum analytical generalization (Yin, 2009).

\section{Results}

\subsection{First Quantitative Approach: Group A versus Group D}

As described in the empirical strategy, our results are presented by using two approaches. First, our treated group consists of firms that have implemented Kaizen continuously during all the periods

We have chosen to implement one-to-one PSM without replacement and Kernel-Based PSM. ${ }^{10}$ 
investigated (Group A). Our initial analysis consists of looking at the differences between all groups described in Figure 1. We focus on the variables considered relevant in the literature review listed in Section 2, which are available in our datasets. As we have two different strategies, we present descriptive statistics when comparing firms implementing Kaizen and those without any management. First, Table 1 shows the mean of each variable considered.

Table-1.

Mean of variables over the three innovation surveys.

\begin{tabular}{l|c|c|c}
\hline Groups & A & D & Both \\
\hline Labor productivity & 39 & 23 & 28 \\
\hline TFP Olley \& Pakes & 5.1 & 4.9 & 5.0 \\
\hline TFP Levinsohn \& Petrin & 3.4 & 3.3 & 3.3 \\
\hline Cost/revenue & $64 \%$ & $64 \%$ & $64 \%$ \\
\hline Margin & $67 \%$ & $68 \%$ & $68 \%$ \\
\hline Export/revenue & $11 \%$ & $8 \%$ & $9 \%$ \\
\hline Product innovation & $68 \%$ & $26 \%$ & $38 \%$ \\
\hline Process innovation & $78 \%$ & $35 \%$ & $48 \%$ \\
\hline Firm's size (number of workers) & 639 & 267 & 377 \\
\hline Physical investment per worker & 8.2 & 7.4 & 7.6 \\
\hline R\&D workers/total & $1.5 \%$ & $0.1 \%$ & $0.5 \%$ \\
\hline Production workers/total & $72 \%$ & $79 \%$ & $77 \%$ \\
\hline Competition (HHI) & 0.030 & 0.033 & 0.032 \\
\hline Multinational status & $28 \%$ & $11 \%$ & $16 \%$ \\
\hline Firm's growth & $12 \%$ & $6 \%$ & $8 \%$ \\
\hline Number of observations & 392 & 940 & 1.332 \\
\hline
\end{tabular}

Table-2.

Kaizen's determinants - Probit of Kaizen Adopters (Group A) versus Non-Adopters (Group D).

\begin{tabular}{|c|c|c|c|}
\hline Variables & Parameter & Standard deviation & p-value \\
\hline Labor Productivity & $0.05^{*}$ & $(0.033)$ & $9.7 \%$ \\
\hline Costs/Revenue & 0.09 & $(0.056)$ & $12.5 \%$ \\
\hline Margin & $-0,14^{*}$ & $(0.082)$ & $9.6 \%$ \\
\hline Exports/Revenue & -0.0001 & $(0.001)$ & $62.3 \%$ \\
\hline Product Innovation & $0,49^{* * * *}$ & $(0.060)$ & $0.0 \%$ \\
\hline Process Innovation & $0,64 * * *$ & $(0.058)$ & $0.0 \%$ \\
\hline Number of Workers & 0.11 & $(0.189)$ & $57.1 \%$ \\
\hline No of Workers Squared & 0.018 & $(0.015)$ & $21.8 \%$ \\
\hline Non-skilled/Total Workers & $-0,42^{* * * *}$ & $(0.133)$ & $0.2 \%$ \\
\hline Physical Invest/No Workers & $0,08^{*} * *$ & $(0.019)$ & $0.0 \%$ \\
\hline \% R\&D Workers & 3,79 *** & $(0.992)$ & $0.0 \%$ \\
\hline Competition (HHI) & $-0,64^{* *}$ & $(0.032)$ & $4.7 \%$ \\
\hline Multinational & $0,15^{* *}$ & $(0.071)$ & $3.2 \%$ \\
\hline Firm's Growth & -0.02 & $(0.085)$ & $82.6 \%$ \\
\hline Observations & 3,456 & Year Dummy & Yes \\
\hline R-squared & 0.255 & Sector Dummy & Yes \\
\hline
\end{tabular}

Notes: Robust standard errors in parentheses (cluster at the firm level); *** $\mathrm{p}<0.01,{ }^{* *} \mathrm{p}<0.05,{ }^{*} \mathrm{p}<0.1$. 
As shown, Kaizen adopters (Group A) tend to present higher performance in some variables (labor productivity, exports, size, innovation, multinational, and growth), yet very similar in others (TFP, cost/revenue, and margin). ${ }^{11}$ Two other variables (competition measured by HHI and physical investment per worker) show some differences (around 10\%), they do not present statistical differences considering their standard deviation. ${ }^{12}$ Looking at labor productivity, it is feasible to see that Kaizen adopters are $69 \%$ more productive than non-adopters. However, Kaizen adopters are different as well in other attributes and this large difference in terms of labor productivity can be explained by the fact, they are larger, export more, and others. Based on the previous description of the empirical strategy, our first approach is to perform PSM so that differences between adopters and non-adopters are minimized on observable attributes. To implement the PSM, it is essential to estimate what are the relevant indicators that influence the adoption of Kaizen. Therefore, a Probit is estimated using a dummy for the adoption of Kaizen as the dependent variable and several characteristics as independent variables based on the evidence from the literature provided in Section 2. Table 2 provides us the results on which indicators are relevant determinants for the implementation of Kaizen. At first, most of the characteristics used are relevant determinants for the adoption of Kaizen, and they present economic interpretation. Productivity, innovation (product and process), physical investment per worker, the share of $\mathrm{R} \& \mathrm{D}$ workers, and multinational status present the corresponding estimated parameter, in which a positive correlation with the adoption of Kaizen exists. Furthermore, firms with higher-margins tend to have lower incentives to implement Kaizen, which is also consistent with the idea firms facing higher competition tend to implement more Kaizen. This evidence is further corroborated by the measure of how markets are concentrated. In sectors with higher concentration (less competition), firms have fewer incentives to improve their performance through the implementation of Kaizen. Therefore, competition seems to be a key driver for Kaizen adoption. Considering most of these characteristics, we perform a PSM and ATE for two methods to estimate total factor productivity (TFP): Olley and Pakes (1996); Levinsohn and Petrin (2003). In other words, we find for each Kaizen adopter one non-adopter which is like this treated firm based on all characteristics used in the Probit apart from the productivity measure. Figure 2 plots the K-density distribution of the p-score derived from the PSM, considering all nonadopters (before the PSM) and only those matched with a Kaizen adopter (after the PSM). ${ }^{13}$
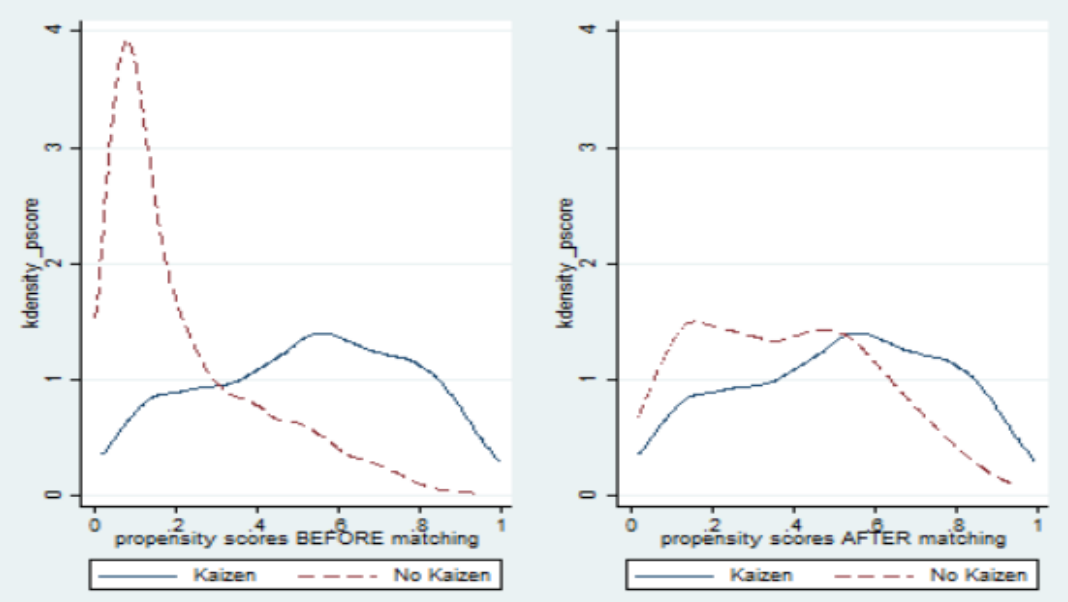

Figure-2.

Kernel density (K-density) of Kaizen Adopters (Group A) versus Non-Adopters (Group D) before and after the Propensity Score Matching (all years).

Two measures of Total Factor Productivity (TFP) are considered (Levinsohn \& Petrin, 2003; Olley \& Pakes, 1996). Further details are 11 available upon request.

We use Herfindahl-Hirschman Index (HHI) as a measure of concentration. ${ }^{12}$

Full descriptive statistics for all variables used in the PSM previous and after it are available in Appendix $3 .{ }^{13}$ 
As shown, differences between Kaizen adopters and non-adopters are significant as previously presented in Table 1. However, the distribution of non-adopters matched with Kaizen adopters becomes more similar after the PSM, which denotes that selection bias has been reduced. Given that adopters and matched non-adopters become similar after matching, the following procedure is to see if there is a premium for implementing Kaizen in different sets of performance indicators. Table 3 reports the ATE outcomes for the three productivity measures described previously for two PSM methods: one-to-one without replacement; Kernel-based.

Table-3.

Results of ATE (Group A versus D)

\begin{tabular}{l|c|c|c|c}
\hline PSM Method & \multicolumn{2}{|c|}{ One-to-one } & \multicolumn{2}{c}{ Kernel } \\
\hline Variables & ATE & P-value & ATE & P-value \\
\hline TFP Levinsohn \& Petrin & $0.084^{*}$ & $6.5 \%$ & $0.070^{*}$ & $7.7 \%$ \\
\hline TFP Olley \& Pakes & $0.085^{*}$ & $10.0 \%$ & $0.080^{*} * *$ & $0.3 \%$ \\
\hline Notes: ${ }^{* * *} \mathrm{p}<0.01,{ }^{* *} \mathrm{p}<0.05,{ }^{*} \mathrm{p}<0.1$.
\end{tabular}

Among all measures considered, our outcomes suggest a premium of around $8 \%$ in total factor productivity considering all methods. ${ }^{14}$ Therefore, this evidence informs us that Kaizen firms tend to have a higher performance compared to others not implementing any management practice even after controlling for the important determinants of its adoption. Considering that Kaizen adopters are implementing this management practice for at least nine years, our initial interpretation is that productivity improvements are observed in the long term. However, we do not have information on some firms' characteristics which might be affecting our results as well as we do not know what happens after the introduction of the Kaizen management practice. For instance, information on capital ownership, such as whether it is a family-owned firm, is not available and there is robust evidence in the literature that family-owned firms are less productive. Ownership generally remains constant over time, therefore applying techniques that might eliminate time-invariant characteristics allow us to overcome this specific shortcoming. As DID tackles this drawback, our next approach can consider it by uncovering when these impacts materialize.

\subsection{Second Quantitative Approach: Groups B and C versus Group D}

Our analysis shifts to those firms which we assumed had adopted Kaizen during the investigated period. First, we needed to evaluate whether our matching pre-Kaizen shows reasonable adherence between adopters and non-adopters. A way to show that is by checking whether the distribution of pscore from Kaizen and non-Kaizen firms become similar after the matching. Figure 3 shows the p-score K-density before and after the matching in 2008. ${ }^{15}$ As observed, the distributions are not so similar before the PSM, but after pairing non-adopters with Kaizen firms differences diminish. ${ }^{16}$ As firms are extremely similar in 2008 after matching, our assumption is that matched firms do not present any difference in terms of productivity, export status, size, and others before implementing Kaizen. In other words, matched firms in treatment and control groups exhibit similar pre-intervention attributes, which is a necessary condition to obtain the effects of Kaizen adoption. However, other unobservable attributes might interfere in the performance of firms after the introduction of Kaizen, such as firms' ownership. If these unobservable characteristics are time-invariant, DID can eliminate them. Thus, Table 4 shows our DID results contrasting those treated firms (group B) against a group of matched firms that have not implemented any kind of management practice (group C). ${ }^{17}$

Similar results are obtained using other methods, such as Caliper, and are available upon request. ${ }^{14}$

Probit results for this matching are reported in Appendix 3. Moreover, similar descriptive statistics provided in Appendix 3 for matched ${ }^{15}$

firms from groups A and D are also available upon request for matched firms from groups B and C against D

For parsimony, we restrict our matching to one-to-one in this case as differences with other methods are minimal. ${ }^{16}$

For robustness check, we have also considered firms beginning to implement Kaizen according to the last innovation survey. Outcomes using ${ }^{17}$

this extra group (isolated our jointly with our treatment group B)provide similar interpretations and are available upon request. 

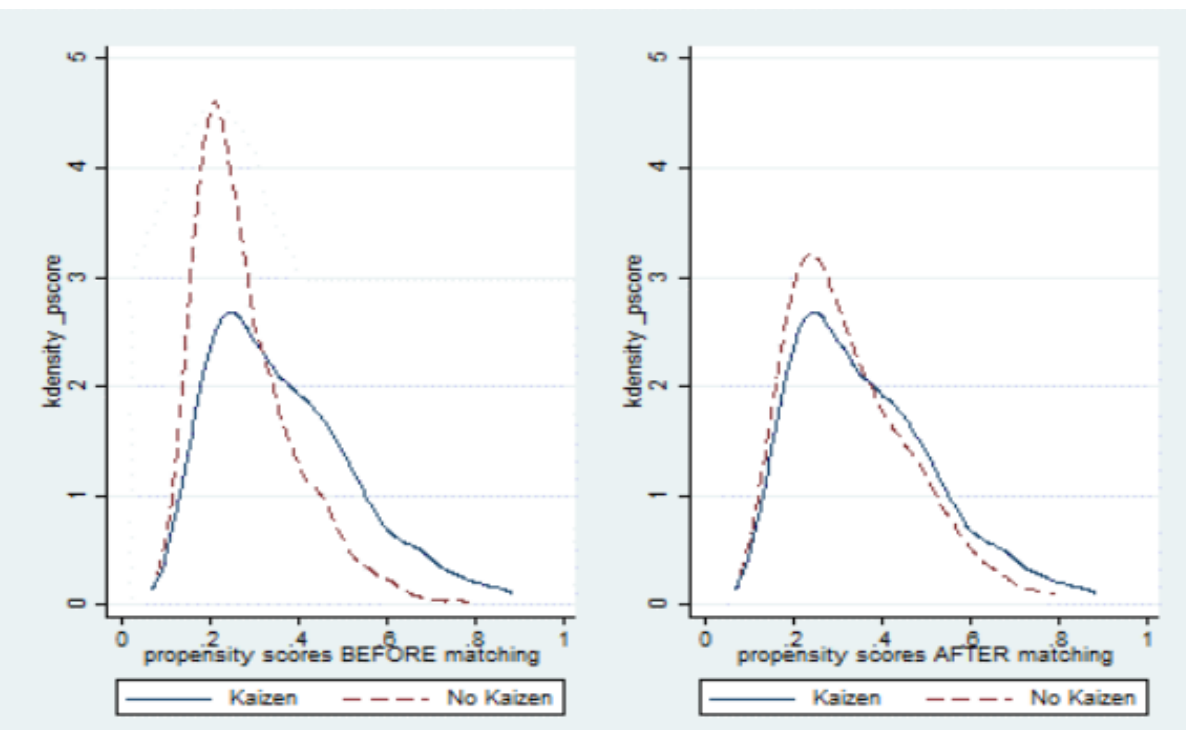

Figure-3.

Kernel density (K-density) of Kaizen Adopters in 2011 (Groups B) versus Non-Adopters (Group D) before and after the Propensity Score Matching in 2008.

Now, we have investigated not only productivity measures but also other variables which are evidenced in the literature as correlated to better management practices. However, we will present only those showing robust evidence in the DID for these extra variables and productivity measures. In other words, all other performance indicators do not show any kind of impact from implementing Kaizen, such as firms' growth, margin, and others. ${ }^{18}$ Therefore, our focus of the DID approach is on: TFP; firm's size; product and process innovation; and share of $R \& D$ workers. ${ }^{19}$ Columns for each variable are first without any control followed by another considering the full set of controls.

Before looking at the impact of Kaizen, controls present the expected sign in most of the outcomes. For instance, multinational firms are larger, innovate more, and show higher productivity. Considering the Kaizen's impact, initially, we observe that Kaizen is not able to improve a firm's productivity after its implementation. ${ }^{20}$ Considering that we observed a productivity premium in the ATE while comparing groups $\mathrm{A}$ and $\mathrm{D}$, our interpretation is that Kaizen promotes productivity gains but when it materializes is not feasible to detect in a short period, at least not during our investigated period (six years from the two last waves from PINTEC). Therefore, we conclude that Kaizen might induce higher productivity in the long term (maybe over a decade), while in the short-term firms still need to adapt to this new management approach, and benefits are not observed in the short run. Therefore, our interpretation is: it might require a longer period to observe an impact of Kaizen on a firm's productivity, as already argued in the literature (see Higuchi et al. (2019)). As DID eliminates any time-invariant unobservable variables, such as ownership, another explanation might be that now after eliminating these unobservable factors, firms do not differ in terms of productivity. As there is robust evidence in the literature that family-owned firms are less productive and our datasets do not provide this particular time-invariant information, then if matched firms from non-adopters are family-owned firms and Kaizen adopters not, perhaps initial positive effects of Kaizen when comparing A and D might be due to ownership and not the Japanese management practice.

Outcomes using these other variables are available upon request. ${ }^{18}$

We present only results for Levinshon \& Petrin method in Table 4, but outcomes for Olley and Pakes show similar interpretation and are 19 available upon request.

Similar outcomes are observed using the other measure of productivity (Olley and Pakes) and are available upon request. ${ }^{20}$ 
Table-4.

Results of DID with paired firms from groups B versus D.

\begin{tabular}{|c|c|c|c|c|c|c|c|c|c|c|}
\hline \multirow[b]{2}{*}{ Variables } & \multicolumn{2}{|c|}{ TFP Lev \& Petrin } & \multicolumn{2}{|c|}{ Product Innovation } & \multicolumn{2}{|c|}{ Process Innovation } & \multicolumn{2}{|c|}{ Size } & \multicolumn{2}{|c|}{ R\&D Workers / Total } \\
\hline & $\begin{array}{c}\text { No } \\
\text { Controls }\end{array}$ & $\begin{array}{c}\text { With } \\
\text { Controls }\end{array}$ & $\begin{array}{c}\text { No } \\
\text { Controls }\end{array}$ & $\begin{array}{c}\text { With } \\
\text { Controls }\end{array}$ & $\begin{array}{c}\text { No } \\
\text { Controls }\end{array}$ & $\begin{array}{c}\text { With } \\
\text { Controls }\end{array}$ & $\begin{array}{c}\text { No } \\
\text { Controls }\end{array}$ & $\begin{array}{c}\text { With } \\
\text { Controls }\end{array}$ & $\begin{array}{c}\text { No } \\
\text { Controls }\end{array}$ & $\begin{array}{c}\text { With } \\
\text { Controls }\end{array}$ \\
\hline \multirow[t]{2}{*}{ Dummy Kaizen } & 0.060 & 0.099* & $0.195^{* * * *}$ & $0.086^{* * * *}$ & $0.142^{* * * *}$ & 0.035 & $0.508^{* * * *}$ & $0.350^{* * * *}$ & $0.003 * * * *$ & 0.001 \\
\hline & $(0.062)$ & $(0.056)$ & $(0.031)$ & $(0.029)$ & $(0.032)$ & $(0.030)$ & $(0.069)$ & $(0.065)$ & $(0.001)$ & $(0.001)$ \\
\hline \multirow[t]{2}{*}{ Kaizen Impact } & -0.026 & 0.018 & $0.158^{* * * *}$ & 0.040 & $0.248^{* * * *}$ & O.179**** & $0.112^{* * * *}$ & $0.068^{*}$ & $0.006^{* * * *}$ & $0.004^{* * *}$ \\
\hline & $(0.023)$ & $(0.033)$ & $(0.032)$ & $(0.032)$ & $(0.036)$ & $(0.035)$ & $(0.026)$ & (0.037) & $(0.001)$ & $(0.001)$ \\
\hline \multirow[t]{2}{*}{ TFP } & - & - & - & -0.009 & - & 0.005 & - & $-0.078^{* *}$ & - & $0.001^{* *} *$ \\
\hline & - & - & - & $(0.010)$ & - & $(0.009)$ & - & $(0.034)$ & - & $(0.001)$ \\
\hline \multirow[t]{2}{*}{ Product Innovation } & - & -0.042 & - & - & - & $0.462^{*} * * *$ & - & 0.335*** & - & $0.010^{* * * *}$ \\
\hline & - & $(0.045)$ & - & - & - & $(0.019)$ & - & $(0.051)$ & - & $(0.001)$ \\
\hline \multirow[t]{2}{*}{ Process Innovation } & - & 0.019 & - & $0.402^{* * * *}$ & - & - & - & 0.046 & - & 0.003**** \\
\hline & - & $(0.035)$ & - & $(0.018)$ & - & - & - & $(0.041)$ & - & $(0.001)$ \\
\hline \multirow[t]{2}{*}{ Number of Workers } & - & 0.061 & - & -0.007 & - & 0.001 & - & - & - & $-0.007^{*}$ \\
\hline & - & $(0.152)$ & - & $(0.051)$ & - & $(0.047)$ & - & - & - & (0.004) \\
\hline \multirow[t]{2}{*}{ No of Workers Squared } & - & -0.010 & - & 0.005 & - & 0.001 & - & - & - & 0.000 \\
\hline & - & $(0.012)$ & - & $(0.004)$ & - & $(0.004)$ & - & - & - & $(0.000)$ \\
\hline \multirow[t]{2}{*}{ \% R\&D Workers } & - & $1.972^{* * *}$ & - & $3.316^{* * * *}$ & - & $0.985^{* * * *}$ & - & $-2.260 * *$ & - & - \\
\hline & - & $(0.789)$ & - & $(0.613)$ & - & $(0.335)$ & - & $(1.019)$ & - & - \\
\hline \multirow[t]{2}{*}{ Costs / Revenue } & - & -0.440 **** & - & $0.032^{*} *$ & - & -0.014 & - & $-0.204^{* * * *}$ & - & -0.001 \\
\hline & - & $(0.051)$ & - & $(0.015)$ & - & $(0.017)$ & - & $(0.052)$ & - & $(0.001)$ \\
\hline \multirow[t]{2}{*}{ Margin } & - & $-0.225^{* * *}$ & - & $-0.044^{*}$ & - & -0.003 & - & 0.220**** & - & 0.002 \\
\hline & - & $(0.069)$ & - & $(0.026)$ & - & $(0.024)$ & - & $(0.074)$ & - & $(0.001)$ \\
\hline \multirow[t]{2}{*}{ Exports / Revenue } & - & $-0.003^{*} *$ & - & $-0.001^{* * * *}$ & - & -0.000 & - & $0.007^{*} * *$ & - & 0.000 \\
\hline & - & $(0.001)$ & - & (0.000) & - & (0.000) & - & $(0.002)$ & - & $(0.000)$ \\
\hline \multirow[t]{2}{*}{$\begin{array}{l}\text { Non-Skilled / Total } \\
\text { Workers }\end{array}$} & - & $0.830^{* * * *}$ & - & $-0.245^{* * * *}$ & - & $0.115^{* * * *}$ & - & -0.021 & - & $-0.013^{* * * *}$ \\
\hline & - & (0.139) & - & $(0.047)$ & - & $(0.044)$ & - & $(0.160)$ & - & $(0.005)$ \\
\hline \multirow[t]{2}{*}{$\begin{array}{l}\text { Physical Investment } \\
\text { per Worker }\end{array}$} & - & $-0.043^{* * *}$ & - & 0.003 & - & $0.027^{*} * *$ & - & $0.068^{* * * *}$ & - & 0.000 \\
\hline & - & $(0.012)$ & - & $(0.005)$ & - & $(0.005)$ & - & $(0.015)$ & - & $(0.000)$ \\
\hline
\end{tabular}

Journal of Contemporary Research in Business, Economics and Finance

ISSN: $2641-0265$
Vol. 3, No. 4, pp. 84-108, 2021

DOI: $10.33094 / 26410265.2021 .34 .84 .108$

(C) 2021 by the authors; licensee Learning Gate 


\begin{tabular}{|c|c|c|c|c|c|c|c|c|c|c|}
\hline Firm's Growth & - & 0.005 & - & 0.012 & - & 0.037 & - & $0.575^{* * * *}$ & - & -0.000 \\
\hline & - & $(0.050)$ & - & $(0.024)$ & - & $(0.027)$ & - & $(0.069)$ & - & $(0.001)$ \\
\hline \multirow[t]{2}{*}{ Productivity Growth } & - & $0.416^{* * *}$ & - & 0.026 & - & -0.075 & - & -0.158 & - & $-0.004^{*}$ \\
\hline & - & $(0.186)$ & - & $(0.055)$ & - & $(0.057)$ & - & $(0.130)$ & - & $(0.002)$ \\
\hline \multirow[t]{2}{*}{ Competition (HHI) } & - & $-2.445^{* * * *}$ & - & $-0.251^{* * * *}$ & - & 0.045 & - & $0.946^{* * *}$ & - & -0.000 \\
\hline & - & $(0.168)$ & - & $(0.094)$ & - & $(0.097)$ & - & $(0.402)$ & - & $(0.003)$ \\
\hline \multirow[t]{2}{*}{ Multinational } & - & $0.215^{* * * *}$ & - & 0.059** & - & -0.025 & - & $0.160^{*}$ & - & 0.001 \\
\hline & - & $(0.053)$ & - & $(0.023)$ & - & $(0.023)$ & - & $(0.083)$ & - & $(0.001)$ \\
\hline Observations & 3,480 & 3,082 & 3,481 & 3,082 & 3,481 & 3,082 & 3,480 & 3,082 & 3,481 & 3,082 \\
\hline R-squared & 0.069 & 0.190 & 0.092 & 0.353 & 0.094 & 0.308 & 0.069 & 0.190 & 0.030 & 0.108 \\
\hline Year FX & Yes & Yes & Yes & Yes & Yes & Yes & Yes & Yes & Yes & Yes \\
\hline Controls & $\mathrm{No}$ & Yes & $\mathrm{No}$ & Yes & $\mathrm{No}$ & Yes & $\mathrm{No}$ & Yes & $\mathrm{No}$ & Yes \\
\hline
\end{tabular}


As once it was eliminated in the DID, Kaizen might not induce higher productivity. Although plausible, family-owned firms are more present in small and medium enterprises (SME), which is not the case of our investigation, since non-adopters and matched firms are large firms (on average, more than 500 employees). Given that scenario, our most comfortable interpretation remains that Kaizen might induce higher productivity in the long term.

In other variables, we can see positive effects from Kaizen adoption. For instance, there are robust results on Kaizen increasing firm size, the measure by the number of employees. As the share of production workers is not impacted from the DID approach yet the share of R\&D workers is, we conclude that this expansion of employees is biased towards high-skilled workers. Thus, Kaizen adopters tend to become larger than non-adopters by increasing the number of skilled workers. Aside from the number of employees, it is also feasible to see a robust impact on process innovations and to some extent product innovation (without controls). As Kaizen is a management practice with the involvement of the full workforce, in which each employee is entitled to suggest changes, an increase of innovation as a whole is a sign that Kaizen promotes the exchange of ideas to improve the firm's performance. As they are innovation outputs, both can induce higher productivity as described by the literature of innovation, see the model proposed by Crépon, Duguet, and Mairessec (1998). So, we conclude that Kaizen can impact productivity determinants in the short term, yet productivity per se only in the long run. ${ }^{21}$

\subsection{Qualitative Approach}

As mentioned before, the goal of our qualitative analysis was to better understand quantitative results derived from PINTEC and PIA's microdata. Interviewed firms showed different characteristics, which helped us generalize our results. For instance, firms that carried out Kaizen since its creation (Alfa and Beta) reported that Kaizen was intrinsically associated with their organizational culture. On the other hand, Gama stated that Kaizen was adopted to achieve higher competitiveness and recover market share lost to other competitor firms that had adopted Kaizen.

All our interviewees also pointed out that the use and adoption of Kaizen were related to the need to create improvements without increasing expenses, which is an important aspect of Kaizen. According to many of the interviewees, the main idea behind Kaizen's adoption was to improve their performance by spending nearly nothing. Our empirical findings on the lack of impact of Kaizen on investment of physical capital per worker validate these qualitative assessments. One interviewee told us that Kaizen was used to reduce the amount of reprocessing - e.g. the number of times the same process is done on the assembly line. This underlines the company's concern with process innovation, which was highly associated with the adoption of Kaizen in our quantitative analysis. Product innovation is less prominent, although changes in process areas can improve the quality of the final product.

Other interesting results underline how workers' participation correlates to part of the continuous improvement in the companies. The workers of all the companies are obliged to propose suggestions frequently and may be rewarded financially or by recognition within the company. While the financial compensation is modest and more of a symbolic gesture, it is an effective way to involve employees in making suggestions. These suggestions often result in small but important changes in the assembly line, which correlate with improvements in process innovation.

Another further outcome came after we asked employees about their recent results regarding Kaizen. One of the interviewees told us that he canceled the hiring of more than 100 professionals when evaluating the implementation of a new plant, most of them on the production line. This result supports our empirical findings that workers who adopt kaizen tend to have a lower percentage of production workers. However, as explained by the interviewee, this work has created a demand for workers with higher levels of education to verify the efficiency of the plant. Given this result, two conclusions emerge. First, although it is difficult to generalize when implementing Kaizen, companies tend to hire more

Results are qualitative similar using all firms from Group D (in other words, without matching) and are available upon request. ${ }^{21}$ 
workers than others, since production expands more than those who do not implement it because these companies show a constant growth, which confirms our empirical conclusions about the total number of workers. Secondly, it provides some evidence that by implementing Kaizen, companies can increase the demand for skilled workers rather than unskilled workers (from the production line). However, more research is needed using more detailed information on workers' skills (such as education and experience) available from other data sets to investigate the impact on the heterogeneity of workers. ${ }^{22}$

Our interviewees stated that the benefits of continuous improvements may not reflect in productivity in the short term because most of the efficiency gains are on improving the time at work from employees in the production line, which does not necessarily increase the speed of producing a good. For example, one suggestion from employees to use their working time most efficiently could be to clean the workstation after each unit of the product instead of cleaning it only at the end of the workday, which leads to longer working hours. This change generates more organized workplaces and a sense of greater importance for the work. Many Kaizen practices help diminishes environmental impacts but do not translate into higher profits or productivity in the short run, even being considered equally important. In the end, we saw that most Kaizen efforts affect companies in the medium and long term, especially as it takes time for employees to believe in these tools. Our quantitative results are in line with these opinions because there is a productivity bonus (ATE), but they are not detectable after Kaizen implementation (DID).

Besides the results that dialogue with the quantitative approach, we found other evidence that helps us to understand the effects of the adoption and use of Kaizen in companies. First, it is important to share some of our respondents' key responses on what it means to work in a Kaizen-adopter company. All of them stated that their work experience changed after they came into more contact with the Kaizen philosophy, despite their previous knowledge of this management practice. Most of the statements considered the search for the root problem in all aspects of industrial production and a deeper understanding of the company's processes. Kaizen implies the search for permanent solutions and not just quick and short-term solutions to industrial bottlenecks.

An interesting aspect of the influence of Kaizen in the daily life of the interviewee is related to their positions in the company. Kaizen is applicable to all areas of the company, but the interviewees said that they only felt how it really worked after they had contacted the production assembly lines. Since continuous improvements are easier to see on an assembly line than on office space - especially due to metrics - it makes sense that Kaizen is seen as more important in the production area. This was the case for all respondents since production assembly lines appeared to be more suitable for Kaizen practices than the departments of other companies. This is consistent with our findings that the percentage of production workers for Kaizen adopters is lower, so this management practice is the long-term saving of labor on the production line.

It is also important to situate the effectiveness of Kaizen as a management tool in the Brazilian business environment, taking into account some of the recent economic fluctuations in the domestic market. Despite the use of Kaizen for decades, employees claim that the drop in sales after 2008 was extremely important to stimulate some of the Kaizen techniques in the firm. that need to reduce costs consider kaizen to be a cheap and effective way to turn the tide. For Beta, it was the perfect moment to deepen Kaizen practices within the firm. For Alfa, it was also an opportune time to share these practices more strongly with its suppliers - before 2008, these suppliers were navigating the economic boom and saw no need to implement kaizen tools. However, after 2008, some suppliers asked for help in implementing Kaizen and, ultimately, this meant a better relationship between the company and its suppliers.

Relação Anual de Informação Social (RAIS) from the Ministry of Labor provides detailed information of each formal Brazilian firm like 22 education, experience and others. 
Table-5.

Summary of companies' responses to interviews.

\begin{tabular}{|c|c|c|c|c|c|}
\hline & Questions derived fron & quantitative results & & Other results & \\
\hline & $\begin{array}{l}\text { Reasons for adopting } \\
\text { Kaizen }\end{array}$ & Kaizen advantages & Kaizen’s impacts & $\begin{array}{l}\text { Kaizen-adopter firms } \\
\text { and their employees }\end{array}$ & $\begin{array}{l}\text { Kaizen and Brazilian } \\
\text { business environment }\end{array}$ \\
\hline \multirow{3}{*}{ Alfa } & \multirow{3}{*}{$\begin{array}{l}\text { Kaizen is associated } \\
\text { with their } \\
\text { organizational } \\
\text { culture }\end{array}$} & Diminishes reprocessing & $\begin{array}{l}\text { Optimization on the } \\
\text { allocation of employees } \\
\text { inside the firm - the lower } \\
\text { percentage of production } \\
\text { workers }\end{array}$ & \multirow{3}{*}{$\begin{array}{l}\text { Kaizen is easily } \\
\text { noticeable in } \\
\text { production lines but } \\
\text { may also be used in } \\
\text { other company areas }\end{array}$} & $\begin{array}{l}\text { Cultural barriers were not } \\
\text { relevant even considering } \\
\text { differences between Brazilian } \\
\text { and Japanese cultures }\end{array}$ \\
\hline & & $\begin{array}{lr}\text { Increases } & \text { process } \\
\text { innovation; not so } \\
\text { relevant for product } \\
\text { innovation }\end{array}$ & \multirow{2}{*}{$\begin{array}{l}\text { Productivity may not } \\
\text { increase in the short-term, } \\
\text { but affects the firm in the } \\
\text { long-term }\end{array}$} & & \multirow{2}{*}{$\begin{array}{l}\text { The economic crisis in Brazil } \\
\text { was a timely moment to } \\
\text { share Kaizen practices with } \\
\text { its suppliers }\end{array}$} \\
\hline & & $\begin{array}{l}\text { Increases employee's } \\
\text { sense of belonging to } \\
\text { the firm }\end{array}$ & & & \\
\hline \multirow[b]{2}{*}{ Beta } & \multirow{2}{*}{$\begin{array}{l}\text { Kaizen is associated } \\
\text { with their } \\
\text { organizational } \\
\text { culture }\end{array}$} & \multirow{2}{*}{$\begin{array}{l}\text { Increases process } \\
\text { innovation; not so } \\
\text { relevant for product } \\
\text { innovation }\end{array}$} & \multirow{2}{*}{$\begin{array}{l}\text { Productivity may not } \\
\text { increase in the short-term, } \\
\text { but affects the firm in the } \\
\text { long-term }\end{array}$} & \multirow{2}{*}{$\begin{array}{l}\text { Kaizen is easily } \\
\text { noticeable in } \\
\text { production lines but } \\
\text { may also be used in } \\
\text { other company areas }\end{array}$} & $\begin{array}{l}\text { The economic crisis in Brazil } \\
\text { was a timely moment to } \\
\text { deepen Kaizen practices }\end{array}$ \\
\hline & & & & & $\begin{array}{l}\text { Cultural barriers were not } \\
\text { relevant even considering } \\
\text { differences between Brazilian } \\
\text { and Japanese cultures }\end{array}$ \\
\hline \multirow[t]{2}{*}{ Gama } & $\begin{array}{l}\text { Adoption after } \\
\text { merger with Asian } \\
\text { company (firm's } \\
\text { culture changes) }\end{array}$ & $\begin{array}{l}\text { Improvements without } \\
\text { much spending }\end{array}$ & $\begin{array}{l}\text { Increased demand for } \\
\text { skilled workers rather than } \\
\text { nonskilled workers }\end{array}$ & \multirow{2}{*}{$\begin{array}{ll}\text { Kaizen is only } \\
\text { considered as a tool } \\
\text { for production line } \\
\text { work }\end{array}$} & $\begin{array}{l}\text { It took longer for employees } \\
\text { to accept Kaizen because the } \\
\text { firm did not have anything } \\
\text { similar prior to the merger } \\
\text { with an Asian-based } \\
\text { company }\end{array}$ \\
\hline & $\begin{array}{l}\text { Competitive pressure } \\
\text { and need to get more } \\
\text { competitive }\end{array}$ & $\begin{array}{l}\text { Increases process } \\
\text { innovation; not as much } \\
\text { relevant for product } \\
\text { innovation }\end{array}$ & $\begin{array}{l}\text { Productivity may not } \\
\text { increase in the short-term, } \\
\text { but affects the firm in the } \\
\text { long-term }\end{array}$ & & $\begin{array}{l}\text { The company's former } \\
\text { corporate culture was more } \\
\text { of a barrier than Brazilian's } \\
\text { culture }\end{array}$ \\
\hline
\end{tabular}


Our interviewees shared their experience of working with Kaizen for years at their production site but also reported experiences in other production sites - including in other countries. Literature has previously shown that cultural and business environment can affect productivity (Bloom \& Van Reenen, 2010) but our respondents claimed that Kaizen positive effects are observed regardless of the company's location. Kaizen can adapt to different scenarios and the results can be seen in the short, medium, and long term if used correctly. Table 5 summarizes the results of the interviews in the research.

\section{Concluding Remarks}

In this paper, we investigate the effects of Kaizen on a firm's performance in Brazil with both quantitative and qualitative approaches. Overall, our hypothesis is that Kaizen is an appropriate approach to improve a firm's performance, especially in the context of financial constraints because it requires low levels of investments. Moreover, a more competitive environment tends to induce firms to implement Kaizen.

Our quantitative empirical outcomes suggest a productive premium for Kaizen adopters. When comparing the performance of adopters versus non-adopters, our outcomes identify a premium of $8 \%$ on TFP in Brazilian firms when estimating the average treatment effect. However, our evidence is not able to detect whether this productivity improvement is observed in a short-term period (six years) when estimating the impact by the difference-in-differences approach. Our findings suggest that Kaizen might require a long-term period to obtain the gains of implementing this management practice. Our findings contrast to other studies on management, which found immediate impact (Gallego \& Gutiérrez, 2017; Mahajan et al., 2012). Considering that our dataset comprehends medium and large firms, one possible explanation might be that medium and large firms require longer periods for the effects to materialize.

Nevertheless, our results suggest that Kaizen is an important tool to enhance innovation. In our difference-in-differences approach, process innovation is increased after the implementation of Kaizen. As an innovation output, it eventually impacts productivity. Therefore, we believe that the channel for Kaizen impacting productivity is through the causality well established in the literature of innovation, which is innovation output leading to productivity improvement. Our interpretation in this regard is based on our results that we detect an impact of Kaizen on innovation on firms implementing this management practice, while the productivity premium is noticed in Kaizen adopters for around a decade at minimum. Another side effect of Kaizen is that adopters tend to increase their size after implementing it since we observed that the number of workers increases in firms implementing Kaizen, especially those in $\mathrm{R} \& \mathrm{D}$ activities.

Our qualitative approach evidenced that the impact of Kaizen on firms' productivity is a long-term process since improvements might not be accounted for in the short term. However, there is a general feeling of improvement in other aspects right after implementing Kaizen practices that translate to better results after some time. Therefore, we believe that the time horizon investigated in this research to verify when these effects on productivity materialize requires a longer period, as argued by Higuchi et al. (2019).

Although this paper provides some evidence on how a Kaizen management approach might affect firms' performance, as evidenced in previous research (Higuchi et al., 2019; Higuchi et al., 2017; Mano, Iddrisu, Yoshino, \& Sonobe, 2012) there is still room for a deeper understanding on the impacts. Focusing on Kaizen, for example, we were not able to investigate whether it reduces accidents at work as we did not have the employer-employee dataset. Having this dataset, we would be able to address this question and others regarding workforce indicators. Looking broadly, it is also interesting to investigate management as a whole, which might provide further evidence on firms' performances. In summary, a different set of venues are still underexplored in the impacts of management on firms' performances, but our quantitative and qualitative findings suggest that a careful investigation is required for the external validity of the findings from the literature. 


\section{References}

Bloom, N., Sadun, R., Van Reenen, J., Attanasio, O., Bertrand, M., \& Gibbons, R. (2016). Management as a technology? (pp. 16133). NBER Working Paper, No. 22327.

Bloom, N., Genakos, C., Sadun, R., \& Van Reenen, J. (2012). Management practices across firms and countries. Academy of Management Perspectives, 26(1), 12-33. Available at: https://doi.org/10.5465/amp.201 1.0077.

Bloom, N., Dorgan, S., Dowdy, J., \& Van Reenen, J. (2007). Management practice and productivity. Quarterly Journal of Economics, 122(4), 1351-1408.

Bloom, N., \& Van Reenen, J. (2010). Why do management practices differ across firms and countries? Journal of Economic Perspectives, 24(1), 203-224. Available at: https://doi.org/10.1257/jep.24.1.203.

Bloom, N., Lemos, R., Sadun, R., Scur, D., \& Van Reenen, J. (2014). JEEA-FBBVA lecture 2013: The new empirical economics of management. Journal of the European Economic Association, 12(4), 835-876. Available at: https://doi.org/10.1111/jeea.12094.

Burch, P., \& Heinrich, C. J. (2016). Mixed methods for policy research and program evaluation. Thousand Oaks, California, USA: Sage Publications.

Crépon, B., Duguet, E., \& Mairessec, J. (1998). Research, innovation and productivi[Ty: An econometric analysis at the firm level. Economics of Innovation and new Technology, 7(2), 115-158. Available at: https://doi.org/10.1080/10438599800000031.

Gallego, J. M., \& Gutiérrez, L. H. (2017). Quality management system and firm performance in an emerging economy: The case of Colombian manufacturing industries. Washington DC: Inter-American Development Bank (IADB).

Gibbons, R., \& Henderson, R. (2011). Relational contracts and organizational capabilities. Organization Science, 23(5), 13501364. Available at: https://doi.org/10.1287/orsc.1110.0715.

Higuchi, Y., Mhede, E. P., \& Sonobe, T. (2019). Short- and medium-run impacts of management training: An experiment in Tanzania. World Development, 114, 220-236. Available https://doi.org/https://doi.org/10.1016/j.worlddev.2018.10.002.

Higuchi, Y., Nam, V. M., \& Sonobe, T. (2017). Management skill, entrepreneurial motivation, and enterprise survival: Evidence from randomized experiments and repeated surveys in Vietnam. Unpublished Technical Report.

Hosono, A., Shimada, G., \& Page, J. (2020). Workers, managers, productivity-Kaizen in developing countries. Singapore: Palgrave Macmillan.

Karlan, D., Knight, R., \& Udry, C. (2015). Consulting and capital experiments with microenterprise tailors in Ghana. Journal of Economic Behavior \& Organization, 118, 281-302. Available at: https://doi.org/10.1016/j.jebo.2015.04.005.

Levinsohn, J., \& Petrin, A. (2003). Estimating production functions using inputs to control for unobservables. The Review of Economic Studies, $70(2), 317-341$. Available at: https://doi.org/10.1111/1467-937x.00246.

Mahajan, A., Eifert, B., McKenzie, D., Roberts, J., \& Bloom, N. (2012). Does management matter? Evidence from India. The Quarterly Journal of Economics, 128(1), 1-51. Available at: https://doi.org/10.1093/qje/qjs044.

Mano, Y., Iddrisu, A., Yoshino, Y., \& Sonobe, T. (2012). How can micro and small enterprises in Sub-Saharan Africa become more productive? The impacts of experimental basic managerial training. World Development, 40(3), 458-468. Available at: https://doi.org/10.1016/j.worlddev.2011.09.013.

McKensie, D., \& Puerto, S. (2017). Growing markets through business training for female entrepreneurs: A market-level randomized experiment in Kenya. World Bank Policy Research Working Paper, No. 7993.

Olley, G. S., \& Pakes, A. (1996). The dynamics of productivity in the telecommunications equipment industry. Econometrica, 64(6), 1263. Available at: https://doi.org/10.2307/2171831.

Patton, M. Q. (2002). Qualitative research and evaluation methods (3rd ed.). Thousand Oaks, California, USA: Sage Publications.

Roberts, J. (2018). Needed: More economic analyses ofmanagement. International Journal of the Economics of Business, 25(1), 3-10. Available at: https://doi.org/10.1080/13571516.2017.1403199.

Siggelkow, N. (2007). Persuasion with case studies. Academy of Management Journal, 50(1), 20-24. Available at: https://doi.org/10.5465/amj.2007.24160882.

Syverson, C. (2011). What determines productivity? Journal of Economic Literature, 49(2), 326-365. Available at: https://doi.org/10.1257/jel.49.2.326.

Valdivia, M. (2015). Business training plus for female entrepreneurship? Short and medium-term experimental evidence from Peru. Journal of Development Economics, 113, 33-51. Available at: https://doi.org/10.1016/j.jdeveco.2014.10.005.

Yin, R. K. (2009). Case study research: Design and methods. Essential guide to qualitative methods in organizational research (5th ed.). Thousand Oaks, California, USA: Sage Publications. 


\section{Appendix-1. List of variables}

Table-A.1.

Description of variables

\begin{tabular}{|c|c|c|}
\hline Variables & Variable description & Source \\
\hline Labor Productivity & Value-Added/Number of Employees & PIA \\
\hline Added Value & Added Value & PIA \\
\hline Number of Employees & Number of Employees & PIA \\
\hline Physical Investment & Total Investment & PIA \\
\hline Physical Investment per Worker & Total Investment/Number of Employees & PIA \\
\hline Capital Stock & $\begin{array}{l}\text { Capital Stock calculated by Perpetual Inventory } \\
\text { (using Investment) }\end{array}$ & PIA \\
\hline Intermediary Consumption & Expenditure in Intermediaries & PIA \\
\hline Total Production Value & Value of Total Production (before taxes) & PIA \\
\hline Energy Consumption & Expenditure in Electricity and Fuel Expenditure & PIA \\
\hline TFP Olley \& Pakes & $\begin{array}{l}\text { Estimated using Production, Capital, Employees, } \\
\text { Intermediaries, and Investment }\end{array}$ & PIA \\
\hline TFP Levinshon \& Petrin & $\begin{array}{l}\text { Estimated using Production, Capital, Employees, } \\
\text { Intermediaries, and Energy Cons. }\end{array}$ & PIA \\
\hline Total Cost & Total Cost & PIA \\
\hline Total Revenue & $\begin{array}{l}\text { Total Revenue (including Financial Revenue, for } \\
\text { example) }\end{array}$ & PIA \\
\hline Firms' Growth & Total Revenue Growth & PIA \\
\hline Cost/Revenue & Total Cost/Total Revenue & PIA \\
\hline Ebitda & Operational Profits plus Amortization & PIA \\
\hline Margin & EBITDA/Value Added & PIA \\
\hline Export/Revenue & Share of Exports in Total Revenue & PIA \\
\hline Production Workers & Number of Production Workers & PIA \\
\hline Production Workers/Total & Production Workers/Total Employees & PIA \\
\hline Kaizen Identification & $\begin{array}{l}\text { Dummy for Organizational Innovation \& Labor } \\
\text { Participation }\end{array}$ & PINTEC \\
\hline Product Innovation & $\begin{array}{l}\text { Dummy for Introduction of a New Product in the last } \\
\text { three years }\end{array}$ & PINTEC \\
\hline Process Innovation & $\begin{array}{l}\text { Dummy for Introduction of a New Process in the last } \\
\text { three years }\end{array}$ & PINTEC \\
\hline Share of R\&D Workers & Number of R\&D Workers/Total Number of Workers & PINTEC \\
\hline Multinational Status & Dummy for Firms for Foreign Ownership & PINTEC \\
\hline
\end{tabular}

Appendix-2. Information used to define Kaizen from the Brazilian Innovation Survey (PINTEC/IBGE)

\section{Organization definition}

Inovação organizacional compreende a implementação de novas técnicas de gestão ou de significativas mudanças na organização do trabalho e nas relações externas da empresa, com vistas a melhorar o uso do conhecimento, a eficiência dos fluxos de trabalho ou a qualidade dos bens ou serviços. Deve ser resultado de decisões estratégicas tomadas pela direção e constituir novidade organizativa para a empresa.

Não são incluídas: fusões e aquisições, mesmo sendo a primeira vez. 


\section{Questions on organization innovation}

Durante o período entre 2012-2014, a empresa implementou alguma das atividades relacionadas a seguir?

Q. 188 - Novas técnicas de gestão para melhorar rotinas e práticas de trabalho, assim como o uso e a troca de informações, de conhecimento e habilidades na empresa. Por exemplo: reengenharia dos processos de negócio, gestão do conhecimento, controle da qualidade total, sistemas de formação/treinamento, sistemas de informações gerenciais (SIG), ERP (planejamento dos recursos do negócio) etc.

Q. 190 - Novos métodos de organização do trabalho para melhor distribuir responsabilidades e poder de decisão, como o estabelecimento do trabalho em equipe, a descentralização ou integração de departamentos etc.

Definition and questions were withdrawn from page 11 from the innovation questionnaire which is described on page 94 from PINTEC 2014.

Appendix-3. Further evidence.

Appendix-3.1. Descriptive statistics: Paper versus PINTEC.

Table-A.2.

Average of the main variables.

\begin{tabular}{l|c|c}
\hline 2008/2011/2014 & Paper & PINTEC \\
\hline Labor Productivity & 28.29 & 27.50 \\
\hline TFP Olley \& Pakes & 5.00 & 4.99 \\
\hline TFP Levinsohn \& Petrin & 3.315 & 3.310 \\
\hline Cost/Revenue & $63.82 \%$ & $64.42 \%$ \\
\hline Margin & $68.02 \%$ & $67.98 \%$ \\
\hline Export/Revenue & $9.52 \%$ & $9.39 \%$ \\
\hline Product Innovation & $42.43 \%$ & $42.18 \%$ \\
\hline Process Innovation & $51.76 \%$ & $52.00 \%$ \\
\hline Firm's Size (Number of Workers) & 398 & 361 \\
\hline Physical Investment per Worker & 7.67 & 7.70 \\
\hline R\&D Workers/Total & $0.59 \%$ & $0.68 \%$ \\
\hline Production Workers/Total & $76.4 \%$ & $76.1 \%$ \\
\hline Competition (HHI) & 0.032 & 0.031 \\
\hline Multinational Status & $17.24 \%$ & $17.67 \%$ \\
\hline Firm's Growth & $8.83 \%$ & $8.86 \%$ \\
\hline Number of Observations & 1,735 & 3,412 \\
\hline
\end{tabular}


Appendix-3.2. Descriptive statistics between groups A and D

Table-A.3.

Comparing means for labor productivity.

\begin{tabular}{|c|c|c|c|c|c|c|c|c|}
\hline \multirow[t]{2}{*}{ Variable } & \multirow{2}{*}{$\begin{array}{c}\text { Unmatched } \\
\text { Matched }\end{array}$} & \multicolumn{2}{|c|}{ Mean } & \multirow[b]{2}{*}{$\%$ Bias } & \multirow[b]{2}{*}{ \% Reduction |Bias } & \multicolumn{2}{|c|}{ t-test } & \multirow[b]{2}{*}{$\mathbf{V}(\mathbf{T}) / \mathbf{V}(\mathbf{C})$} \\
\hline & & Treated & Control & & & $\mathbf{t}$ & $p>|t|$ & \\
\hline \multirow[t]{2}{*}{ Cost/Revenue } & $\mathrm{U}$ & -0.45169 & -0.47239 & 4.2 & & 1.09 & 0.275 & $0.58^{*}$ \\
\hline & $\mathrm{M}$ & -0.45169 & -0.43373 & -3.6 & 13.2 & -0.94 & 0.349 & $0.81^{*}$ \\
\hline \multirow[t]{2}{*}{ Margin } & $\mathrm{U}$ & -0.3924 & -0.38264 & -3.0 & & -0.79 & 0.429 & $0.65 *$ \\
\hline & M & -0.3924 & -0.39706 & 1.4 & 52.1 & 0.37 & 0.713 & 0.91 \\
\hline \multirow[t]{2}{*}{ Export/Revenue } & $\mathrm{U}$ & 11.412 & 9.1015 & 11.7 & & 3.18 & 0.001 & 1.01 \\
\hline & $\mathrm{M}$ & 11.412 & 10.784 & 3.2 & 72.8 & 0.74 & 0.459 & 1.02 \\
\hline \multirow{2}{*}{ Product Innovation } & $\mathrm{U}$ & 0.68918 & 0.26063 & 95.0 & & 26.15 & 0.000 &. \\
\hline & $\mathrm{M}$ & 0.68918 & 0.69565 & -1.4 & 98.5 & -0.33 & 0.744 & . \\
\hline \multirow[t]{2}{*}{ Process Innovation } & $\mathrm{U}$ & 0.78168 & 0.35621 & 95.1 & & 25.24 & 0.000 & . \\
\hline & $\mathrm{M}$ & 0.78168 & 0.77613 & 1.2 & 98.7 & 0.31 & 0.756 & . \\
\hline \multirow[t]{2}{*}{ Firm's Size } & $\mathrm{U}$ & 6.5043 & 5.6288 & 79.9 & & 22.94 & 0.000 & $1.72^{*}$ \\
\hline & $\mathrm{M}$ & 6.5043 & 6.5139 & -0.9 & 98.9 & -0.18 & 0.858 & 0.95 \\
\hline \multirow[t]{2}{*}{ N. of Workers Squared } & $\mathrm{U}$ & 43.824 & 32.566 & 79.2 & & 23.32 & 0.000 & $2.24 *$ \\
\hline & M & 43.824 & 44.025 & -1.4 & 98.2 & -0.27 & 0.786 & 0.90 \\
\hline \multirow[t]{2}{*}{ Physical Investment per Worker } & $\mathrm{U}$ & 8.2279 & 7.3526 & 54.1 & & 14.37 & 0.000 & $0.75^{*}$ \\
\hline & M & 8.2279 & 8.2349 & -0.4 & 99.2 & -0.10 & 0.919 & $0.80^{*}$ \\
\hline \multirow{2}{*}{$\%$ Production Workers } & $\mathrm{U}$ & 0.71525 & 0.78011 & 32.2 & & -9.01 & 0.000 & $1.34^{*}$ \\
\hline & $\mathrm{M}$ & 0.71525 & 0.71635 & -0.5 & 98.3 & -0.12 & 0.902 & $1.16^{*}$ \\
\hline \multirow[t]{2}{*}{ \% R\&D Workers } & $\mathrm{U}$ & 0.01593 & 0.00388 & 37.1 & & 11.69 & 0.000 & $5.02^{*}$ \\
\hline & $\mathrm{M}$ & 0.01593 & 0.01345 & 7.6 & 79.4 & 1.49 & 0.135 & $1.44^{*}$ \\
\hline \multirow[t]{2}{*}{ Competition (HHI) } & $\mathrm{U}$ & 0.02762 & 0.03224 & -5.7 & & -1.45 & 0.148 & $0.40^{*}$ \\
\hline & M & 0.02762 & 0.02626 & 1.7 & 70.4 & 0.53 & 0.594 & 1.08 \\
\hline \multirow[t]{2}{*}{ Multinational Status } & $\mathrm{U}$ & 0.2914 & 0.12547 & 41.7 & & 12.08 & 0.000 & . \\
\hline & $\mathrm{M}$ & 0.2914 & 0.27567 & 4.0 & 90.5 & 0.81 & 0.417 & . \\
\hline \multirow[t]{2}{*}{ Firm's Growth } & $\mathrm{U}$ & 0.11246 & 0.0644 & 15.1 & & 4.27 & 0.000 & $1.46^{*}$ \\
\hline & $\mathrm{M}$ & 0.11246 & 0.11852 & -1.9 & 87.4 & -0.45 & 0.650 & $1.65^{*}$ \\
\hline Sample & Ps R2 & LR chi2 & $\mathrm{p}>\operatorname{chi} 2$ & Mean Bias & Mean Bias & $\mathrm{B}$ & $\mathrm{R}$ & $\% \operatorname{Var}$ \\
\hline Unmatched & 0.254 & 1089.29 & 0.000 & 42.6 & 37.1 & $133.7^{*}$ & 1.37 & 90 \\
\hline Matched & 0.002 & 6.42 & 0.930 & 2.3 & 1.4 & 10.9 & 1.04 & 50 \\
\hline
\end{tabular}

Notes: * If variance ratio outside $[0.89 ; 1.13]$ for $\mathrm{U}$ and $[0.89 ; 1.13]$ for M. ** If $\mathrm{B}>25 \%$, R outside $[0.5 ; 2]$. 
Table-A.4.

Comparing means for TFP by Olley and Pakes.

\begin{tabular}{|c|c|c|c|c|c|c|c|c|}
\hline \multirow[t]{2}{*}{ Variable } & \multirow{2}{*}{$\begin{array}{l}\text { Unmatched } \\
\text { Matched }\end{array}$} & \multicolumn{2}{|c|}{ Mean } & \multirow[b]{2}{*}{$\%$ Bias } & \multirow[b]{2}{*}{\begin{tabular}{|l|l|}
$\%$ Reduction & Bias
\end{tabular}} & \multicolumn{2}{|c|}{ t-test } & \multirow[b]{2}{*}{$\mathbf{V}(\mathbf{T}) / \mathbf{V}(\mathbf{C})$} \\
\hline & & Treated & Control & & & $\mathbf{T}$ & $\mathbf{p}>|\mathbf{t}|$ & \\
\hline \multirow[t]{2}{*}{ Cost/Revenue } & $\mathrm{U}$ & -0.45169 & -0.47239 & 4.2 & & 1.09 & 0.275 & $0.58^{*}$ \\
\hline & M & -0.45169 & -0.43373 & -3.6 & 13.2 & -0.94 & 0.349 & $0.81^{*}$ \\
\hline \multirow[t]{2}{*}{ Margin } & $\mathrm{U}$ & -0.3924 & -0.38264 & -3.0 & & -0.79 & 0.429 & $0.65^{*}$ \\
\hline & M & -0.3924 & -0.39706 & 1.4 & 52.1 & 0.37 & 0.713 & 0.91 \\
\hline \multirow[t]{2}{*}{ Export/Revenue } & $\mathrm{U}$ & 11.412 & 9.1015 & 11.7 & & 3.18 & 0.001 & 1.01 \\
\hline & M & 11.412 & 10.784 & 3.2 & 72.8 & 0.74 & 0.459 & 1.02 \\
\hline \multirow[t]{2}{*}{ Product Innovation } & $\mathrm{U}$ & 0.68918 & 0.26063 & 95.0 & & 26.15 & 0.000 & . \\
\hline & M & 0.68918 & 0.69565 & -1.4 & 98.5 & -0.33 & 0.744 & . \\
\hline \multirow[t]{2}{*}{ Process Innovation } & $\mathrm{U}$ & 0.78168 & 0.35621 & 95.1 & & 25.24 & 0.000 & . \\
\hline & $\mathrm{M}$ & 0.78168 & 0.77613 & 1.2 & 98.7 & 0.31 & 0.756 & . \\
\hline \multirow[t]{2}{*}{ Firm's Size } & $\mathrm{U}$ & 6.5043 & 5.6288 & 79.9 & & 22.94 & 0.000 & $1.72^{*}$ \\
\hline & $\mathrm{M}$ & 6.5043 & 6.5139 & -0.9 & 98.9 & -0.18 & 0.858 & 0.95 \\
\hline \multirow[t]{2}{*}{ N. of Workers Squared } & $\mathrm{U}$ & 43.824 & 32.566 & 79.2 & & 23.32 & 0.000 & $2.24^{*}$ \\
\hline & $\mathrm{M}$ & 43.824 & 44.025 & -1.4 & 98.2 & -0.27 & 0.786 & 0.90 \\
\hline \multirow[t]{2}{*}{ Physical Investment per Worker } & $\mathrm{U}$ & 8.2279 & 7.3526 & 54.1 & & 14.37 & 0.000 & $0.75^{*}$ \\
\hline & $\mathrm{M}$ & 8.2279 & 8.2349 & -0.4 & 99.2 & -0.10 & 0.919 & $0.80^{*}$ \\
\hline \multirow[t]{2}{*}{ \% Production Workers } & $\mathrm{U}$ & 0.71525 & 0.78011 & 32.2 & & -9.01 & 0.000 & $1.34^{*}$ \\
\hline & $\mathrm{M}$ & 0.71525 & 0.71635 & -0.5 & 98.3 & -0.12 & 0.902 & $1.16^{*}$ \\
\hline \multirow[t]{2}{*}{ \% R\&D Workers } & $\mathrm{U}$ & 0.01593 & 0.00388 & 37.1 & & 11.69 & 0.000 & $5.02^{*}$ \\
\hline & M & 0.01593 & 0.01345 & 7.6 & 79.4 & 1.49 & 0.135 & $1.44^{*}$ \\
\hline \multirow[t]{2}{*}{ Competition (HHI) } & $\mathrm{U}$ & 0.02762 & 0.03224 & -5.7 & & -1.45 & 0.148 & $0.40^{*}$ \\
\hline & $\mathrm{M}$ & 0.02762 & 0.02626 & 1.7 & 70.4 & 0.53 & 0.594 & 1.08 \\
\hline \multirow[t]{2}{*}{ Multinational Status } & $\mathrm{U}$ & 0.2914 & 0.12547 & 41.7 & & 12.08 & 0.000 & . \\
\hline & $\mathrm{M}$ & 0.2914 & 0.27567 & 4.0 & 90.5 & 0.81 & 0.417 & . \\
\hline \multirow[t]{2}{*}{ Firm's Growth } & $\mathrm{U}$ & 0.11246 & 0.0644 & 15.1 & & 4.27 & 0.000 & $1.46^{*}$ \\
\hline & $\mathrm{M}$ & 0.11246 & 0.11852 & -1.9 & 87.4 & -0.45 & 0.650 & $1.65^{*}$ \\
\hline Sample & Ps R2 & LR chi2 & $\mathrm{p}>\operatorname{chi} 2$ & Mean Bias & Mean Bias & $\mathrm{B}$ & $\mathrm{R}$ & $\% \operatorname{Var}$ \\
\hline Unmatched & 0.254 & 1089.29 & 0.000 & 42.6 & 37.1 & $133.7^{*}$ & 1.37 & 90 \\
\hline Matched & 0.002 & 6.42 & 0.930 & 2.3 & 1.4 & 10.9 & 1.04 & 50 \\
\hline
\end{tabular}

Notes: * If variance ratio outside $[0.89 ; 1.13]$ for $\mathrm{U}$ and $[0.89 ; 1.13]$ for M. ** If $\mathrm{B}>25 \%$, R outside $[0.5 ; 2]$ 
Table-A.5.

Comparing Means for TFP by Levinshon and Petrin

\begin{tabular}{|c|c|c|c|c|c|c|c|c|}
\hline \multirow[t]{2}{*}{ Variable } & \multirow{2}{*}{$\begin{array}{c}\text { Unmatched } \\
\text { Matched } \\
\end{array}$} & \multicolumn{2}{|c|}{ Mean } & \multirow[b]{2}{*}{$\%$ Bias } & \multirow[b]{2}{*}{ \% Reduction |Bias } & \multicolumn{2}{|c|}{ t-test } & \multirow[b]{2}{*}{$\mathrm{V}(\mathrm{T}) / \mathrm{V}(\mathbf{C})$} \\
\hline & & Treated & Control & & & $\mathbf{t}$ & $\mathbf{p}>|\mathbf{t}|$ & \\
\hline \multirow[t]{2}{*}{ Cost/Revenue } & $\mathrm{U}$ & -0.45169 & -0.47239 & 4.2 & & 1.09 & 0.275 & $0.58^{*}$ \\
\hline & $\mathrm{M}$ & -0.45169 & -0.43373 & -3.6 & 13.2 & -0.94 & 0.349 & $0.81^{*}$ \\
\hline \multirow[t]{2}{*}{ Margin } & $\mathrm{U}$ & -0.3924 & -0.38264 & -3.0 & & -0.79 & 0.429 & $0.65^{*}$ \\
\hline & $\mathrm{M}$ & -0.3924 & -0.39706 & 1.4 & 52.1 & 0.37 & 0.713 & 0.91 \\
\hline \multirow[t]{2}{*}{ Export/Revenue } & $\mathrm{U}$ & 11.412 & 9.1015 & 11.7 & & 3.18 & 0.001 & 1.01 \\
\hline & $\mathrm{M}$ & 11.412 & 10.784 & 3.2 & 72.8 & 0.74 & 0.459 & 1.02 \\
\hline \multirow[t]{2}{*}{ Product Innovation } & $\mathrm{U}$ & 0.68918 & 0.26063 & 95.0 & & 26.15 & 0.000 & . \\
\hline & $\mathrm{M}$ & 0.68918 & 0.69565 & -1.4 & 98.5 & -0.33 & 0.744 & . \\
\hline \multirow[t]{2}{*}{ Process Innovation } & $\mathrm{U}$ & 0.78168 & 0.35621 & 95.1 & & 25.24 & 0.000 & . \\
\hline & $\mathrm{M}$ & 0.78168 & 0.77613 & 1.2 & 98.7 & 0.31 & 0.756 & . \\
\hline \multirow[t]{2}{*}{ Firm's Size } & $\mathrm{U}$ & 6.5043 & 5.6288 & 79.9 & & 22.94 & 0.000 & $1.72^{*}$ \\
\hline & $\mathrm{M}$ & 6.5043 & 6.5139 & -0.9 & 98.9 & -0.18 & 0.858 & 0.95 \\
\hline \multirow[t]{2}{*}{ N. of Workers Squared } & $\mathrm{U}$ & 43.824 & 32.566 & 79.2 & & 23.32 & 0.000 & $2.24 *$ \\
\hline & $\mathrm{M}$ & 43.824 & 44.025 & -1.4 & 98.2 & -0.27 & 0.786 & 0.90 \\
\hline \multirow[t]{2}{*}{ Physical Investment per Worker } & $\mathrm{U}$ & 8.2279 & 7.3526 & 54.1 & & 14.37 & 0.000 & $0.75^{*}$ \\
\hline & $\mathrm{M}$ & 8.2279 & 8.2349 & -0.4 & 99.2 & -0.10 & 0.919 & $0.80^{*}$ \\
\hline \multirow[t]{2}{*}{ \% Production Workers } & $\mathrm{U}$ & 0.71525 & 0.78011 & 32.2 & & -9.01 & 0.000 & $1.34^{*}$ \\
\hline & $\mathrm{M}$ & 0.71525 & 0.71635 & -0.5 & 98.3 & -0.12 & 0.902 & $1.16^{*}$ \\
\hline \multirow[t]{2}{*}{ \% R\&D Workers } & $\mathrm{U}$ & 0.01593 & 0.00388 & 37.1 & & 11.69 & 0.000 & $5.02 *$ \\
\hline & $\mathrm{M}$ & 0.01593 & 0.01345 & 7.6 & 79.4 & 1.49 & 0.135 & $1.44^{*}$ \\
\hline \multirow[t]{2}{*}{ Competition (HHI) } & $\mathrm{U}$ & 0.02762 & 0.03224 & -5.7 & & -1.45 & 0.148 & $0.40^{*}$ \\
\hline & $\mathrm{M}$ & 0.02762 & 0.02626 & 1.7 & 70.4 & 0.53 & 0.594 & 1.08 \\
\hline \multirow[t]{2}{*}{ Multinational Status } & $\mathrm{U}$ & 0.2914 & 0.12547 & 41.7 & & 12.08 & 0.000 & . \\
\hline & $\mathrm{M}$ & 0.2914 & 0.27567 & 4.0 & 90.5 & 0.81 & 0.417 & . \\
\hline \multirow[t]{2}{*}{ Firm's Growth } & $\mathrm{U}$ & 0.11246 & 0.0644 & 15.1 & & 4.27 & 0.000 & $1.46^{*}$ \\
\hline & $\mathrm{M}$ & 0.11246 & 0.11852 & -1.9 & 87.4 & -0.45 & 0.650 & $1.65^{*}$ \\
\hline Sample & $\mathrm{Ps} \mathrm{R} 2$ & LR chi2 & $\mathrm{p}>$ chi 2 & Mean Bias & Mean Bias & $\mathrm{B}$ & $\mathrm{R}$ & $\% \operatorname{Var}$ \\
\hline Unmatched & 0.254 & 1089.29 & 0.000 & 42.6 & 37.1 & $133.7^{*}$ & 1.37 & 90 \\
\hline Matched & 0.002 & 6.42 & 0.930 & 2.3 & 1.4 & 10.9 & 1.04 & 50 \\
\hline
\end{tabular}

Notes: * If variance ratio outside $[0.89 ; 1.13]$ for $\mathrm{U}$ and $[0.89 ; 1.13]$ for $\mathrm{M}$. *** If $\mathrm{B}>25 \%$, R outside $[0.5 ; 2 \rrbracket$. 
Table-A.6.

Outcomes of the Probit for Kaizen Determinants in 2008.

\begin{tabular}{|c|c|c|}
\hline & $(1)$ & $(2)$ \\
\hline Variables & B versus C - Total & B versus $C$ - Margin \\
\hline \multirow[t]{2}{*}{ Labor Productivity } & 0.070 & 0.023 \\
\hline & $(0.053)$ & $(0.017)$ \\
\hline \multirow[t]{2}{*}{ Costs/Revenue } & 0.026 & 0.008 \\
\hline & $(0.076)$ & $(0.025)$ \\
\hline \multirow[t]{2}{*}{ EBITDA/Value-Added } & -0.127 & -0.041 \\
\hline & $(0.137)$ & $(0.044)$ \\
\hline \multirow[t]{2}{*}{ Exports/Sales } & -0.000 & -0.000 \\
\hline & $(0.002)$ & $(0.001)$ \\
\hline \multirow[t]{2}{*}{ Product Innovation } & $0.275^{* * * *}$ & 0.089**** \\
\hline & $(0.098)$ & $(0.031)$ \\
\hline \multirow[t]{2}{*}{ Process Innovation } & 0.075 & 0.024 \\
\hline & $(0.091)$ & $(0.030)$ \\
\hline \multirow[t]{2}{*}{ Size } & 0.068 & 0.022 \\
\hline & $(0.318)$ & $(0.103)$ \\
\hline \multirow[t]{2}{*}{ Size Sqr } & 0.015 & 0.005 \\
\hline & $(0.026)$ & $(0.008)$ \\
\hline \multirow[t]{2}{*}{ Physical Investment per Employee } & 0.034 & 0.011 \\
\hline & $(0.029)$ & $(0.009)$ \\
\hline \multirow[t]{2}{*}{ Share of Production Workers } & -0.140 & -0.045 \\
\hline & $(0.233)$ & $(0.076)$ \\
\hline \multirow[t]{2}{*}{ Share of R\&D Workers } & 2.453 & 0.795 \\
\hline & $(2.120)$ & $(0.686)$ \\
\hline \multirow[t]{2}{*}{ Competition - HHI } & -0.745 & -0.242 \\
\hline & (0.469) & $(0.152)$ \\
\hline \multirow[t]{2}{*}{ Multinational Status } & 0.131 & 0.043 \\
\hline & $(0.119)$ & $(0.038)$ \\
\hline \multirow[t]{2}{*}{ Employment Growth } & 0.153 & 0.050 \\
\hline & $(0.116)$ & $(0.038)$ \\
\hline Observations & 1,164 & 1,164 \\
\hline Year FX & $\mathrm{No}$ & $\mathrm{No}$ \\
\hline
\end{tabular}

Note: Standard errors in parentheses;

*** $\mathrm{p}<0.01,{ }^{*} * \mathrm{p}<0.05, * \mathrm{p}<0.1$. 
Table-A.7.

Average of the main variable.

\begin{tabular}{l|c|c|c}
\hline $\mathbf{2 0 0 8}$ & Group B & Group C & Total \\
\hline Labor Productivity & 30.18 & 23.05 & 25.44 \\
\hline TFP Olley \& Pakes & 5.06 & 4.94 & 4.98 \\
\hline TFP Levinsohn \& Petrin & 3.32 & 3.30 & 3.30 \\
\hline Cost/Revenue & $63.6 \%$ & $63.8 \%$ & $64.4 \%$ \\
\hline Margin & $68.2 \%$ & $68.2 \%$ & $68.4 \%$ \\
\hline Export/Revenue & $10 \%$ & $8 \%$ & $9 \%$ \\
\hline Product Innovation & $56 \%$ & $26 \%$ & $36 \%$ \\
\hline Process Innovation & $66 \%$ & $35 \%$ & $45 \%$ \\
\hline Firm's Size (Number of Workers) & 469 & 267 & 329 \\
\hline Physical Investment per Worker & 7.87 & 7.35 & 7.56 \\
\hline R\&D Workers/Total & $0.9 \%$ & $0.1 \%$ & $0.5 \%$ \\
\hline Production Workers/Total & $75 \%$ & $79 \%$ & $77 \%$ \\
\hline Competition (HHI) & 0.030 & 0.033 & 0.033 \\
\hline Multinational Status & $21 \%$ & $11 \%$ & $15 \%$ \\
\hline Firm's Growth & $12 \%$ & $6 \%$ & $8 \%$ \\
\hline Number of Observations & 403 & 940 & 1,735 \\
\hline
\end{tabular}

